\title{
O TEATRO COM COMUNIDADE: UMA PROPOSTA PEDAGÓGICA
}

\author{
THEATER WITHIN COMMUNITY: A \\ PAEDAGOGICAL PROPOSAL
}

Maíra Rosa*

\begin{abstract}
RESUMO: Este artigo tem como objetivo compartilhar as formas de ensino aprendizagem em Teatro Comunitário realizadas no bairro Residencial 2000, periferia da cidade de Uberaba/MG, junto às crianças e adolescentes. A pergunta norteadora foi: Como o ensino de teatro dialoga de forma horizontal com tal comunidade? Desta forma, discorreremos sobre metodologias advindas do Teatro do Oprimido de Augusto Boal, dos ensinamentos de Paulo Freire e também das próprias formas e expressões culturais da juventude desta comunidade.
\end{abstract}

Palavras-chave: Educação; Teatro comunitário; Poetry slam.

RESUMEN: Este artículo tiene como objetivo compartir las formas de enseñanza y aprendizaje en el Teatro Comunitario que se realiza en el barrio Residencial 2000, en las afueras de la ciudad de Uberaba / MG, con niños y adolescentes. La pregunta guía fue: ¿Cómo dialoga la educación teatral horizontalmente con una comunidad así? De esta manera, discutiremos metodologías desde el Teatro del Oprimido de Augusto Boal, desde las enseñanzas de Paulo Freire y también desde las propias formas y expresiones culturales de la juventud de esta comunidad.

Palabras Ilaves: Educación; Teatro comunitario; Poesía slam.

\section{A COMUNIDADE EM CENA}

A arte teatral, dentro dos processos educativos, exige um permanente diálogo que ultrapassa a mera questão das subjetividades pessoais e se insere nos sentidos comunitários e sociais vividos pelo arte-educador. E é, dentro destes preceitos, que se faz necessária uma reflexão a fim de fomentar a

\footnotetext{
"Mestre em Artes Cênicas e bacharel em Teatro pela Universidade Federal de Uberlândia (UFU). Graduanda em Pedagogia pelo Instituto Brasil de Ensino e Consultoria (IBRA). Contato: luardeflora@gmail.com
} 
relevância do fazer teatral como prática educativa no contexto das comunidades, sejam elas rurais ou periféricas.

A metodologia teatral que foi empregada dentro deste processo de ensino aprendizagem em teatro, optou por estender a noção da mera representação da estética teatral, da qual como efêmera em sua constituição, sempre assume um caráter provisório, para se estender a compreensão do papel ético do qual o teatro também está inserida.

As metodologias teatrais dentro do campo da Educação, muitas vezes se traduzem em contextos escolares, dentro das aulas de Artes. Porém, também estão presentes nos chamados espaços não formais, como em associações comunitárias, por exemplo. Segundo, aponta Nogueira (2008, p.133), um dos grandes facilitadores do acesso à arte teatral foi o teatrólogo Augusto Boal ${ }^{1}$, tomando por base os ensinamentos do educador popular Paulo Freire. A fim de construir elos com outras formas de saberes que têm como premissa a democratização de suas formas de ensino, temos nas teses desenvolvidas a partir dos livros Pedagogia do Oprimido (1968) e Pedagogia para Autonomia (1996), caminhos que buscaram refletir sobre as relações entre o ensinar e o aprender também em Artes.

Neste viés, o ensinar não é apenas a reprodução de saberes, de forma bancária (FREIRE. 1996, p.57-56), mas antes, parte de uma metodologia crítica que revela as desigualdades sociais, e aponta, a partir disso, uma relação que se fundamenta na troca compartilhada dos saberes. Dentro deste contexto, Teatro do Oprimido de Augusto Boal revela não apenas na perspectiva estética, mas também, como procedimento fundamental para se possa pensar e intervir em diferentes contextos políticos. Suas técnicas assim, tem como objetivo trazer à cena "o ator e o não-ator com vontade de dizer algo através do teatro" (BOAL, 1979).

\footnotetext{
${ }^{1}$ Foi diretor de teatro, dramaturgo e ensaísta brasileiro, uma das grandes figuras do teatro contemporâneo internacional. Fundador do Teatro do Oprimido, que alia o teatro à ação social, suas técnicas e práticas difundiram-se pelo mundo, notadamente nas três últimas décadas do século XX, sendo largamente empregadas não só por aqueles que entendem o teatro como instrumento de emancipação política mas também nas áreas de educação, saúde mental e no sistema prisional.
} 
Com foco na discussão social, as metodologias o Teatro do Oprimido, tiveram grande importância no contexto teatral ao possibilitar a discussão ética do teatro para além da representação estética. É importante destacar que, o teatro que se faz com comunidades, produz um conjunto de metodologias de ensino em artes que envolvem diversos processos, mas que necessariamente passam pelo crivo das pessoas, temas e do próprio contexto social envolvidos na criação cênica. Como definição para o Teatro Comunitário, temos então:

\begin{abstract}
Trata-se de um teatro criado coletivamente, através da colaboração entre artistas e comunidades específicas. Os processos criativos têm sua origem e seu destino voltados para realidades vividas em comunidades de local ou de interesse. De um modo geral, mesmo usando terminologias diferentes, esboça-se um método baseado em histórias pessoais e locais, desenvolvidas a partir de improvisação. Cada terminologia, a seu modo, guarda relações com um processo educativo entendido ou não como transformador. Do meu ponto de vista podemos, no Brasil, chamar essas práticas de Teatro em Comunidades (NOGUEIRA, 2009, p.4).
\end{abstract}

Como forma de fortalecimento dos vínculos socioculturais e educativo, o teatro comunitário vincula-se e projeta a identidade da comunidade como uma prática de descentralização e democratização cultural (TELLES, 2013), que estabelece em seu cerne o protagonismo local frente a outras formas culturais que não dão visibilidade a essas formas culturais.

Tendo como base as ideias de Nogueira (2008), o teatro comunitário é visto como a configuração das relações entre os moradores de um bairro, vila, comunidade local, ou mesmo um grupo de interesse. Na maior parte das vezes orientadas por profissionais das artes cênicas tendo como interesse um elemento de organização desta comunidade em prol do fazer teatral.

Segundo Nogueira, (2007) há pelo menos três modelos de teatro comunitários: "teatro para comunidade", "teatro com comunidade", "teatro por comunidade", que são recorrentes dentro de diversas concepções do fazer artístico com as comunidades, não apenas por estarem dentro do contexto "não teatral", mas por comunicar-se também com associações de bairros, prisões e outros espaços cujo fazer teatral se faça presente. artistas para comunidades periféricas, desconhecendo de antemão 


\begin{abstract}
sua realidade. Caracteriza-se por ser uma abordagem de cima pra baixo, um teatro de mensagem. 2. Teatro com Comunidades: aqui, o trabalho teatral parte de uma investigação de uma determinada comunidade para a criação de um espetáculo. Tanto a linguagem, o conteúdo - assuntos específicos que se quer questionar - ou a forma manifestações populares típicas - são incorporados no espetáculo. A ideia de vinculação a uma comunidade específica estaria ligada à ampliação da eficácia política do trabalho.3. Teatro por Comunidades: o terceiro modelo tem grande influência de Augusto Boal. Inclui as próprias pessoas da comunidade no processo de criação teatral. Em vez de fazer peças dizendo o que os outros devem fazer, passou-se a perguntar ao povo o conteúdo do teatro, ou dar ao povo os meios de produção teatral (NOGUEIRA, 2007, p. 03).
\end{abstract}

Assim, as temáticas ligadas ao teatro comunitário, segundo Nogueira (2007), reforçam a necessidade de observarmos os processos de criação entre o artista, ou professor de teatro, com as comunidades periféricas. Em "termos metodológicos, esta interação exige o enfrentamento de muitas questões: como evitar uma relação de invasão cultural? Como garantir um processo democrático? Como pode se dar a interação de culturas diferentes? Qual o papel do facilitador²?" (NOGUEIRA, 2007, p.03)

Em busca de uma relação horizontal entre o ensino e a aprendizagem em teatro, a solução apontada por Nogueira (2007) discorre sobre a importância das proposições do pedagogo Paulo Freire (1977), para quem o processo de autonomia do conhecimento se dá pelo método dialógico, em respeito aos conhecimentos que são compartilhados. Nesse sentido, tanto a comunidade quanto os "artistas facilitadores", e educadores, somam-se em busca de temas significativos a ambos nas construções cênicas.

Sobre a estética do teatro realizado na comunidade, Nogueira (2007) menciona que se atrela aos movimentos culturais que estão presentes nas próprias comunidades, que trata de padrões particulares que não pode ser julgada segundo parâmetros estranhos a ela.

\footnotetext{
${ }^{2}$ Segundo Nogueira (2007), o "facilitador" é o artista, ou arte educador que, em contato com as comunidades, desenvolve ações de ensino e aprendizagem em teatro.
} 


\section{A ESCUTA DA CULTURA DE RUA}

Dentro dos processos metodológicos do Ensino em Artes, os componentes da cultura de rua, em específico do movimento hip-hop, foram de fundamental importância, dado as expressões poéticas que reforçavam a identidade cultural dos jovens e crianças envolvidas no processo.

Precisávamos, neste contexto, entender como tais poéticas, se organizavam como práticas dentro do contexto social, religando o fazer artístico com o seu compromisso frente às denúncias às desigualdades sociais, comuns aos espaços periféricos.

Neste sentido, as cenas foram elaboradas após o contato com os jogos e exercício teatrais retirados do arsenal de Boal (2009), onde em cada oficina de teatro, era trabalho um tema específico retirado da realidade local. Partindo das temáticas trabalhadas elencadas para a construção da intervenção cênica, temos como recorrentes a violência gerada pela desigualdade social, seja através da violência contra as mulheres, principalmente negras e periféricas, como também, da violência policial.

Assim a questão norteadora de todo esse processo se apresenta enunciada da seguinte forma: como o teatro dialoga com a comunidade periférica do Residencial 2000 em Uberaba MG?

De agosto a dezembro de 20016, o arsenal desenvolvido por Boal (2004), fora por nós completado na medida em que novas questões emergiram tanto do contexto social, quanto do desenvolvimento do trabalho cênico e poético desenvolvido dentro do contexto das oficinas teatrais.

Pudemos assim, escolher e analisar os jogos e exercícios que eram trabalhados durante a oficina e suas funções dentro do contexto de criação. Foi nesse caminho, que apresentamos as ferramentas metodológicas utilizadas no processo criativo, buscando desenvolver o mais objetivamente possível as opções do grupo a partir de suas referências culturais, as quais nos levaram à percepção da potência emancipatória das narrativas advindas dos alunos que participava das aulas de teatro. 
Tais jogos e exercícios teatrais, nos auxiliaram na compreensão das formas democráticas de produção do fazer teatral, como também tornaram visíveis para todos nós, as máscaras de opressão social, presentes nas vivências de cada um dos participantes. Esta mescla entre o que era trabalho no contexto da oficina, com as referências culturais e as vivências sociais trazidas pelos alunos, nos fez entender o sentido que queríamos dar ao teatro que estávamos fazendo.

Assim, surge a contextualização da potência da poética presente dentro do Movimento Hip Hop, através do poetry slam (batalha de poesias), como uma poética identitária serviu de gatilho, junto a construção cênica. O poetry slam (do inglês, batida de poesia) é um campeonato de poesia oral num formato parecido com as batalhas de Mc's e, como num jogo ${ }^{3}$, possui suas regras determinadas: a poesia deve ser autoral, podendo variar de 30 segundos à três minutos e o jogador (ou slammer), não pode utilizar recursos cênicos (instrumentos musicais, figurinos e adereços)

O slam nasce em 1986, em Chicago e vem sendo passado de mão em mão, ou melhor, de palavra em palavra pelos chamados "mestres". No Brasil, a atriz e pesquisadora, Roberta Estrela D’Alva, junto com o Núcleo Bartolomeu de Depoimentos ${ }^{4}$, criaram o primeiro slam, denominado Zona Autônoma da Palavra - ZAP, em 2003.

O slam, nesse sentido, se apresenta como uma modalidade diretamente associada aos princípios do hip hop, não apenas enquanto presença de mecanismos de ação, tais como o jogo com a poesia, os questionamentos sociais e as características particulares de relação com o espaço, mas também pela presença do protagonismo das identidades que compõem tal modalidade.

\footnotetext{
${ }^{3}$ Segundo Huizinga (1980, p. 33): "O jogo é uma atividade ou ocupação voluntária, exercida dentro de certos e determinados limites de tempo e de espaço, segundo regras livremente consentidas, mas absolutamente obrigatórias, dotado de um fim em si mesmo, acompanhado de um sentimento de tensão e de alegria e de uma consciência de ser diferente da 'vida cotidiana'". Entendido aqui como o espaço de compartilhamento de experimentações na vida cotidiana.

${ }^{4}$ O Núcleo Bartolomeu de Depoimentos foi fundado em 1999, e traz como matriz de construção cênica os elementos do hip-hop. O assim chamado teatro hip-hop, nasce de investigações cênicas que partiram da investigação das teatralidades presente do próprio movimento hip-hop, em trabalho com atores profissionais que buscam nesta forma de expressão seu percurso criativo. No caso de nosso trabalho com o Residencial 2000, a proposição do hip-hop, nasce no contexto de criação de cena, a partir dos alunos.
} 
Nossas escolhas poéticas e políticas, retiradas do slams e realocadas no contexto de criação cênica resultantes do processo de oficinas junto ao Residencial 2000, fizeram com que os jovens e crianças, se aproximam também do prazer pela escrita poética, ou seja, retirassem o estigma de uma arte inacessível e caminhassem como protagonistas de suas próprias poéticas.

Para organizarmos como se deu a dinâmica do slam no interior das oficinas, e como esse movimento culminou na criação e apresentação de uma intervenção cênica, apoiamo-nos em três princípios que estão presentes no slam e que também guiaram nosso trabalho teatral com os jovens, a saber: 1) a narrativa, 2) a poesia oral e 3) a celebração coletiva. Esses princípios, que são comuns ao slam e em certo sentido ao próprio teatro, se mostraram, como afirmarmos acima, na forma como organizamos teórica e praticamente o fazer teatral nessa comunidade.

Nosso trabalho, assim, se debruçou na análise da questão da narrativa presente em Walter Benjamin (1987), de forma a possibilitar cada vez mais o reconhecimento da figura do poeta slammer como narrador de seu tempo que partilha a poesia oral, trazendo a ela outros significados sensoriais, tais quais enunciados e por nós discutidos a partir da obra de P. Zumthor (1997).

Com a compreensão da palavra poética, fez-se necessário que trabalhássemos o corpo habitual e mecanizado a fim de compreender a necessidade de não naturalizarmos as desigualdades sociais. Assim, transformar temas do cotidiano em ação corporal era em si retirar o gesto habitual da violência do cotidiano e transformá-lo em gesto que tivesse ao mesmo tempo um sentido pessoal, coletivo e principalmente social. Foi dessa forma que chegamos à discussão em torno do conceito de gestus social enunciado pelo grande B. Brecht (1967).

Se Brecht tinha no gestus social, caminho para onde o ator desenvolveria sua ação, para nós o gestus social servia como mecanismo de denúncia corporal, pois os alunos não representavam personagens e sim eles mesmos e, partindo desses enunciados, foi possível para nós entendermos qual seria os caminhos que iríamos seguir dentro do percurso de criação. 
Tendo a arte de rua como mote à construção dramatúrgica, bem como seu caráter coletivo, optamos por trabalhá-la no formato de coro e corifeu, por acreditarmos nos protagonismos destas vozes em busca de uma identidade narrativa. A poética, a princípio retirada das músicas de rap e utilizada na criação cênica, abriu espaço para outras pesquisas, o que contribuiu na construção dramatúrgica, musical e corporal do teatro realizado com a comunidade do Residencial 2000.

Ao serem mapeados para a criação cênica alguns slams, vimos a potência poética desse encontro, onde a poesia no slam se torna, também, uma forma de manifesto, dado o teor muitas vezes incisivo de temáticas que retratam o "grito" das minorias sociais. Assim sendo, dentro da esfera de construção teatral com comunidades, buscou- se aqui ressaltar a própria produção artística na qual o próprio bairro está inserido, bem como outras perspectivas do fazer teatral com comunidades. Passamos então a descrever como a junção entre os elementos poéticos do hip-hop, em consonância com a linguagem do Teatro do Oprimido deram fora a uma intervenção cênica resultado das oficinas/aulas de teatro.

\section{ENTRECRUZAMENTO DE SABERES E FAZERES}

Nesta parte do trabalho, apresentaremos o resultado do processo de criação cênica criados a partir dos slams. Como já mencionamos, as cenas, foram elaboradas após o contato com os jogos e exercício teatrais retirados do arsenal de Boal (2009). Cada oficina/aula de teatro era trabalhado um tema em específico retirado da realidade local. Partindo das temáticas trabalhadas elencadas para a construção da intervenção cênica, temos como recorrentes a violência gerada pela desigualdade social, seja através da violência contra as mulheres, principalmente negras e periféricas, e da violência policial. Assim, a descrição que se segue, pretende elucidar cena a cena, como trabalhamos a linguagem teatral em contato com a poética presente no slam.

A cena se inicia com a roda se abrindo em direção ao público, e os alunos cantando o refrão do Rap Mandume, do álbum "Sobre Crianças, Quadris, 
Pesadelos e Lições de Casa" (2015) do rapper Emicida ${ }^{5}$. Como cena que abre a intervenção, o refrão aponta, de forma direta a submissão do qual tanto a juventude, quanto os moradores das "quebradas", sofrem por residirem longe dos centros.

Como temática inicial temos a relação de submissão que levou o corpo dos alunos a criarem a imagem do andar com ombros arqueados e do olhar dirigido ao chão. Tal, imagem corporal foi criada e trabalhada a partir dos exercícios de Boal (2004) onde detectamos corpos sempre vencidos pela fadiga cotidiana. Muito alunos tinham vergonha tanto do seu corpo, como do espaço possível de troca, vergonha do bairro etc. No refrão do rap Mandume (EMICIDA, 2016) ${ }^{6}$ temos, então a participação de todos os todos os alunos cantando, que ao caminharem retiram os olhos do chão, arqueiam os corpos e retiram o olhar do chão, direcionando-o diretamente para a plateia.

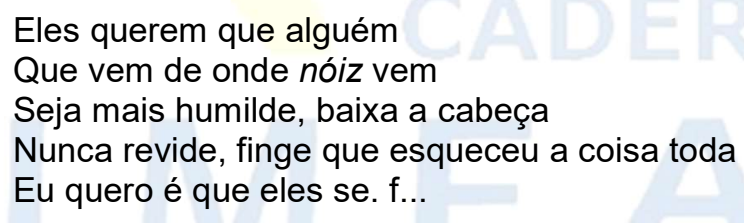

Essa mudança corporal só foi possível tendo como base, o arsenal de jogos já discutidos aqui de Boal (2004), bem como o trabalho de reconstrução da imagem corporal. Ao invés de olharmos para baixo, a proposta era levantar o olhar e mirarmos não mais o chão, mas possíveis horizontes. Desta forma, também incentivados a expressar se pela dança de rua, material de criação já consolidado no bairro, os alunos se observavam como protagonistas artísticos e parte do fazer cultural e social de sua comunidade. Logo, depois de trabalhado a submissão dos corpos, trabalhávamos a resolução daquela imagem corporal.

\footnotetext{
${ }^{5}$ Leandro Roque de Oliveira (São Paulo, 17 de agosto de 1985), mais conhecido pelo nome artístico Emicida, é um rapper, cantor e compositor brasileiro. É considerado uma das maiores revelações do hip hop do Brasil da década de 2000.0 nome "Emicida" é uma fusão das palavras "MC" e "homicida". Por causa de suas constantes vitórias nas batalhas de improvisação, seus amigos começaram a falar que Leandro era um "assassino", e que "matava" os adversários através das rimas. Mais tarde, o rapper criou também um acrônimo para o nome: E.M.I.C.I.D.A. (Enquanto Minha Imaginação Compuser Insanidades Domino a Arte). Disponível em https://pt.wikipedia.org/wiki/Emicida. Acesso: 12 de nov.

${ }^{6}$ EMICIDA. Mandume. 2016. Disponível em: https://www.youtube.com/watch?v=mC vrzqYfQc. Acesso: 12 de nov. 2018.
} 
Se a submissão era parte cotidiana dos corpos periféricos, nossa resolução foi oportunizar uma nova postura corporal que retirasse os ombros caídos e o olhar para chão.

Já a segunda cena criada, parte do primeiro rap7, trazido pelos alunos, e traz como temática a denúncia sobre a violência contra a mulher. Como trabalho de criação das imagens corporais, enquanto uma das alunas repete a frase dentro do contexto da cena, os demais alunos repetem o texto olhando nos olhos da plateia e se abaixando até estarem todos deitados no chão.

\section{A cada quinze segundos uma mulher é agredida no Brasil \\ $E$ a realidade não é nem um pouco cor-de-rosa \\ A cada ano, dois milhões de mulheres são espancadas \\ Por maridos ou namorados.}

A intenção, foi a de retratar a violência, expondo o rebaixamento dos corpos femininos frente às agressões vivenciadas no cotidiano e, o fato das alunas estarem repetindo cada uma a seu tempo a denúncia. Dirigindo seus corpos para o chão de forma lenta, traduz também a necessidade de observarmos o quão os corpos femininos são frágeis, frente às violências descritas. No rap Rosas (2000), do grupo Atitude Feminina, formado apenas por rappers femininas, a denúncia soma-se não apenas ao contexto local do Residencial 2000, mas também, refletem o contexto social do qual as mulheres, e principalmente, as mulheres negras, estão expostas.

Como apontamos anteriormente, esta temática e os seus desdobramentos construía uma relação corporal que pautava-se pela diminuição de seus movimentos, em sinal de recolhimento, submissão e medo, onde cada gesto era pensado tendo como mote esta situação social.

$\mathrm{Na}$ terceira cena, temos que um aluno se levanta e começa a dizer as frases que foram trabalhadas, também dentro de uma das oficinas teatrais. As frases que faziam parte da temática do dia eram trabalhadas posteriormente como um exercício de voz, onde utilizamos o volume, baixo e alto das frases. Se

\footnotetext{
${ }^{7}$ O rap mencionado e da banda ATITUDE FEMININA (Rosas, 2000). Disponível em: https://www.youtube.com/watch?v=0h2f6NaEOml\&start radio=1\&list=RDOh2f6NaEOml\&t=0. Acesso: 21 de nov. 2000.
} 
o aluno escolhesse um tom mais baixo, à frase "você não presta pra nada", tal escolha, para os demais alunos, soava como perversidade, cinismo e intimidade. E se o aluno repetia a frase com um volume de voz mais empostado e alto, aos demais alunos tinham a sensação de briga, o que trazia medo. Esta oficina deve assim, o papel de trabalhar os volumes das falas, bem como, traduzir em forma de sensação corporal o que as mesmas emitem.

Palavras e expressões muito fortes, como "vagabunda", "você não serve para a nada", "preta encardida", "nem para cuidar dos filhos presta", foram retiradas do contexto desta oficina e trabalhadas na criação da cena de modo a experienciar as entonações das falas, como forma a contextualizar tais agressões verbais. Tais agressões, assim, eram analisadas no contexto de criação cênicas, após a exploração de suas tonalidades variadas, e sempre eram ditas por um aluno do sexo masculino, pois entendemos que a figura da opressão se dava no contexto doméstico, tendo a figura do homem como sujeito opressor. Tal cena, nos fez pensar nos meninos que embora poucos, faziam as oficinas teatrais. Como estariam dispostos a refletir sobre as questões referentes ao machismo estrutural, do qual todos fazemos parte? Perguntas cuja a resolução, se davam na criação coletiva das cenas.

Como forma de reação às agressões, as demais alunas/atrizes se levantam e voltam ao centro do círculo e repetem em coro: "É treta preta, muita treta", referência aos versos do slam de Mel Duarte sob o mesmo título ${ }^{8}$. As formas de reação, no contexto da criação dos movimentos dentro desta cena, estão dispostos gestos corporais que foram traduzidos em forma do ato de se levantar, ou se erguer corporalmente, como modo de reação às palavras ofensivas ouvidas no cotidiano social, bem como da união corporal das demais alunas no centro do espaço cênico, como modo de representar a luta coletiva contra estas formas de agressão.

Entendendo que a violência contra a mulher acontece em sua maioria, dentro do âmbito familiar, temos que dentro das oficinas teatrais, a resolução se deu através da experimentação cênica que prenunciava a dilatação da roda dos

\footnotetext{
${ }^{8}$ Além da poesia de Mel Duarte está no livro Verdade Nua e Crua (2016, p. 16) também está disponível no https://www.youtube.com/watch?v=PRegoHZK-Wk, acessado em 4 de abril de 2019.
} 
alunos, e sua contração, como forma de problematizamos tanto o uso do espaço cênico como também sua função na criação.

Tal observação, sobre este movimento de dilatação e contração do espaço da roda, permitiu-nos perceber como a imagem de sua contração, reforçava a ideia da importância da união entre as mulheres. Bem como, a ideia de mãos dadas irmos nos afastando em roda, provocava a sensação de distanciamento tanto corporal como no nível da discussão da temática exposta.

A cena que foi construída dando seguimento como narrativa foi trabalhada a partir do tema da desigualdade social. Como imagem corporal reforçamos a ideia da espera, onde pesquisamos as formas de espera onde a figura do ponto de ônibus. Dentro do contexto da vida de um trabalhador que precisa do transporte público para trabalhar, ou da mãe que precisa levar seus filhos a uma emergência médica, a imagem criada dentro do contexto da oficina, buscava traduzir corporalmente a angústia que esta espera produzia.

Principalmente quando refletimos sobre os meios de transporte que se disponham os mais ricos, ao utilizarem não apenas carros particulares para seus traslados, como também jatinhos e helicópteros. Essa gritante distinção entre os meios de transportes utilizados pelos diferentes contextos sociais, seguiu dentro da construção da cena com a construção mimética de um avião, realizado pelos braços esticados e a agilidade corporal no deslocamento rápido até a plateia. $\mathrm{A}$ cena assim criada, tinha como mote a demonstração das desigualdades sociais, vista através da realidade vivenciada pelos alunos, cujas famílias e eles próprios, passavam pelo déficit do acesso e locomoção.

\footnotetext{
Trabalhar longe e a passagem só aumenta Enquanto eles compram jatinho com a verba da merenda Capitalismo invade acaba com sua renda E só uma cesta básica pra família não dá conta. É treta preta! (DUARTE, 2016, p.16).
}

Na construção da continuidade da poesia de Mel Duarte (2016), os alunos formados pelos adolescentes do sexo masculino simulam assediar as alunas seguindo com os olhos ao cruzarem com elas em cena. Tais alunas, criam dentro da cena um bloco que se desloca de forma conjunta até o espaço onde 
se encontram os outros alunos, e conjuntamente repetem: "É treta preta, muita treta!".

Atriz 1: - É treta preta!

Atriz 2: - Sair na rua numa noite de sexta

Atriz 3: - Esperar o ônibus de volta e ele nunca chega,

Atriz 4: - Daí um malandro safado, no carro quase parado te diz uma pá de besteira

Atriz 5: - E não satisfeito com a humilhação, ainda faz questão de mostrar que está batendo punheta. (DUARTE, 2016, p.16).

Como forma de reação às formas de união empregadas dentro da construção desse bloco, que se desloca até a figura dos alunos que estão como opressores, os mesmos se tornam agora, não apenas a figura do homem, mas também do policial. Esta construção cênica da imagem corporal da figura repressora que representava a polícia, fazia parte do cotidiano dos alunos de teatro e dos moradores do Residencial 2000. Assim, os mesmos atores que assediavam as mulheres se colocam agora como figura opressora da autoridade policial no mesmo segmento da cena e diz: "Enquanto a farda faz a vez do capeta[...]" ( DUARTE, 2016, p.16), enquanto os demais alunos se enfileiram com as mãos na nuca, cabeça baixa e pés separados, posição anunciada pelos policiais quando os mesmo fazem o procedimento de revista.

Uma das alunas ainda fala sobre a possibilidade de haver crianças dentro do procedimento de revista, o que segundo o próprio testemunho do aluno que faz a figura do policial, deixaria os policiais com mais raiva. A figura do policial em cena não se importa com o fato, e simula atirar nos demais em cena. Os alunos finalizam o trecho da poesia de Mel Duarte (2016, p.16) saindo da posição em que estavam e repetem em conjunto a frase em tom baixo "Maldade está solta, eu sei, atenta!".

Em seguida, os atores se espalham e começam a cantar o rap da MC Sofia, Menina Pretinha ${ }^{9}$. Este rap, escolhido pelos alunos, serviu para apaziguar a cena anterior de violência policial reiterando agora, o papel da beleza feminina e negra. A cena criada também foi fruto das experimentações realizadas dentro

\footnotetext{
${ }^{9}$ MC SOFIA. Menina pretinha. 2016. Disponível em: https://accoints.google.com/ServiceLogin?service=mail\&continue=https://mail.google.com/mail/ \&hl=pt-BR\#identifier. Acesso: 12 de nov. 2018.
} 
do contexto das oficinas, o que nos possibilitou colocarmos as danças de rua produzidas como forma de diálogo corporal entre os alunos e o processo de criação teatral desenvolvido nesta intervenção.

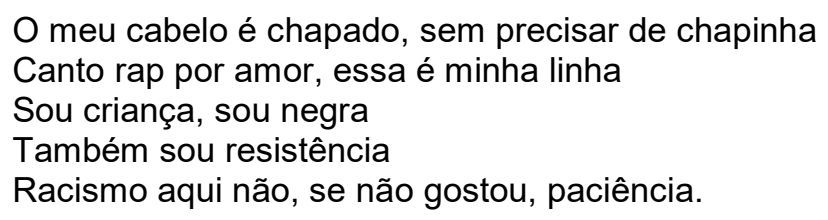

Após cantarem e dançarem, os atores retornam de frente à plateia, e iniciam outra poesia slam de Mel Duarte, "Verdade Seja Dita" (2016, p. 18). Este slam foi um dos primeiros que trabalhamos durante as oficinas de teatro, e reflete a obscuridade da violência que culpabiliza muitas vezes, quem as sofre. A pesquisa sobre esse tema se deu tendo como base a própria linguagem poética e de protesto emitida pelos raps, onde buscamos num primeiro momento, dentro da poética dos raps autoras femininas que discutem essa temática.

Todos dizem: Verdade seja dita! (Uma atriz se posiciona ao centro da roda) Atriz 1: - Você que não mova sua pica para impor respeito a mim. (DUARTE, 2016, p.18).

O aluno, que faz a figura do opressor nas demais falas, retoma um verso da poesia de Mel Duarte, reconfigurando o discurso ao apontar o machismo como algo comum a ambos os sexos. No verso temos, "o seu discurso machista machuca" (2016, p. 18), que, no contexto da poesia, é direcionado aos homens. Na nossa adaptação para a intervenção teatral, o tema machismo foi discutido como uma questão arreigada dentro da sociedade, que pode envolver tanto os homens, como também as mulheres. Ainda no contexto da escolha do tema a ser trabalhado no contexto das oficinas, quando debatemos a questão das violências que acometem as mulheres, o machismo foi levantado como uma das causas.

Ainda dentro das oficinas, trabalhamos com improvisações cujo objetivo seria que em duplas, os alunos pudessem trocar entre si, imagens corporais, frases e palavras que remetesse a figura do opressor (como a do homem machista), e a figura de quem estava sendo oprimido (no caso as mulheres). 
Neste diálogo, onde ora um se assumia como opressor, ora também era oprimido, percebemos que muitas vezes, as mulheres também reproduziam o discurso machista. Logo, junto à criação da intervenção, decidimos colocar os pronomes "meu" e "nosso' no contexto da poesia original de Mel Duarte. Assim, o aluno diz: "O seu, o meu e o nosso discurso machista, machuca", seguindo com as demais alunas as falas:

Atriz 2: - E a cada palavra falha Corta minhas iguais como navalha.

Todos (abrindo para roda ao pé do público): NINGUÉM MERECE SER ESTUPRADA!

Atriz 3: -Violada!

Atriz 4: -Violentada!

Ator: - Seja pelo abuso da farda.

Atriz 5: - Ou por trás de uma muralha

Atriz 1: - Minha vagina não é lixão

Pra dispensar as tuas tralhas

(Em roda um de cada vez): - Canalha!

Atriz 2 : Tanta gente alienada

Que reproduz seu discurso vazio.

(DUARTE, 2016, p.16).

Neste outro momento da cena, os alunos fazem o que chamamos nas oficinas de a "roda da opressão". Esta imagem corporal, da roda formada pelos alunos, também foi pinçada das oficinas, seu objetivo era trabalhar o sentido de ocupação do espaço cênico. Porém, para além deste sentido de estudo do espaço cênico, a roda passou a ser entendida, como local que poderia ter outros significados.

$\mathrm{Na}$ "roda de opressão", que estava presente na cena criada para a intervenção, uma atriz fica ao centro e os demais com os corpos lateralizados ficam em roda com os dedos apontados para ela. E, com falas que subjugam a figura da mulher, os alunos repetem frases e palavras que menosprezam a figura da mulher. A aluna que permanece ao centro ao escutar tais ofensas, desce lentamente até o chão ficando de joelhos, enquanto dois outros alunos caminham por lados opostos em direção à plateia e dizem:

Atrizes 3 e 4: - E não adianta dizer que é só no Brasil

Em todos os lugares do mundo,

Mulheres sofrem com seres sujos 
Que utilizam da força quando não só, até em grupos!

Praticando sessões de estupros que ficam sem justiça.

Atriz 1 (A atriz que estava sendo oprimida se levanta): - Carniça!

( Atrizes retornam aos pés da plateia)

Atriz 2: - Os teus restos nem pros urubus jogaria.

Atriz 3: - Pq animal é bicho sensível,

E é capaz de dar rebuliço no estômago já acostumado com tanto lixo

Atriz 4: - Até quando teremos que suportar?

Mãos querendo nos apalpar?

(Todos se tocam com nojo)

Atriz 5: - Olha bem para mim? Pareço uma fruta?

Onde na minha cara tá estampado: Me chupa?!

Atriz 1: - Se seu músculo enrijece quando digo NÃO pra você

Todos repetem: - E não é não!!!

Atriz 2: - Que vá procurar outro lugar onde o possa meter

Atriz 3: - Filhos dessa pátria,

Mãe gentil? (DUARTE, 2016, p.19).

Neste momento da cena, também inserimos o nosso contexto político local, bem como aqueles que estavam em evidência na mídia. Neste contexto, é bom relembrar que durante o tempo que estive ministrando as aulas de teatro, surge o impeachment de uma presidenta eleita, um golpe à democracia brasileira. Logo, as questões referentes à política nacional, que estavam presentes no slam de Mel Duarte (2016), também foram trabalhadas nas oficinas de teatro. Na poesia original, Mel Duarte (2016) diz: "Enquanto ainda existir Bolsonaro, Cunha e Aécio [...]", os alunos optaram por acrescentar nomes de políticos locais ou em evidência no cenário político, e colocá-los no plural. $\mathrm{Na}$ nossa adaptação, a fala ficou: "Enquanto existirem Bolsonaros, Cunhas, Aécios, Marcos Montes e Temmers...". A cena segue com os alunos falando:

Todos: ... Eu continuo afirmando

Sou filha da luta, da puta

A mesma que aduba o solo fértil

A mesma que te pariu! (DUARTE, 2016, p.17).

Em seguida, temos uma outra música em que trabalhamos uma coreografia com referência nas matrizes africanas que nos serviu para observarmos as semelhanças destas danças, com as danças de rua, e também, as danças advindas da religiosidade de matriz africana. Este tema trabalhado em sala, serviu para que os alunos pudessem se aproximar dos elos que ligavam 
a motivação rítmica, das batidas extraídas dos raps e funks, com a raiz ancestral destas batidas advindas do contexto africano.

Como nossas discussões sempre foram pautadas pela importância do respeito à diversidade, os alunos compreendendo estes princípios do respeito mútuo, independentemente do credo religioso, deveria ser trabalhado como a valorização e reconhecimento destas danças. Logo, como modo de desmistificar o que era uma referência da expressão religiosa advinda dos negros, os alunos retomaram a criação das danças, agora embasadas também pelas danças africanas em busca do resgate à sua ancestralidade. A música escolhida, para que essa matriz identitária fosse respeitosamente compartilhada pelos integrantes da trupe, foi Nasci Preto, Nasci Pobre, de Everson Roriz.
Um menino no morro
Segurando a sua dor
Um menino no asfalto
Sem saber o que é o amor
As pessoas perdidas
Se pisando no pé
A tristeza insistindo
Em dizer quem você é
As crianças brincando
E já morreu
As meninas dançando
$E$ toma que o filho é teu
O país desmoronando
$\mathrm{Na}$ cabeça dos meus
Crise financeira
Mais importante que Deus
O que será que resolve
O seu medo de ter paz?
O que será que resolve
Teu receio de ser mais?
O amor é jogo de azar
E eu nunca tive sorte
Com tanta possibilidade
Nasci preto, nasci pobre
O amor é jogo de azar
E eu nunca tive sorte
Com tanta dignidade
Nasci preto, nasci pobre. ${ }^{10}$

$\mathrm{Na}$ construção desta outra cena, após o momento de canto e dança anteriormente exposto, o aluno sai do espaço cênico e vai em direção a plateia

\footnotetext{
${ }^{10}$ RORIZ, E. Nasci preto, nasci pobre. Disponível em: https://www.letras.mus.br/everton-rorizpreto-nasci-pobre/. Acesso: 03 de dez. 2018.
} 
perguntando se a mesma se acha machista ou racista. Este encontro surge no contexto de trazer a plateia para dentro das discussões que estávamos levantando, bem como, busca a reflexão conjunta sobre esse tema. Experimentado dentro das oficinas de teatro e reverberando o tema machismo e racismo. E com isso, criamos esta cena através da abertura do jogo entre os alunos de teatro e a própria comunidade do Residencial 2000, numa relação que a priore começou informalmente quando dentro dos nossos ensaios ao céu aberto, a plateia participava com risos desconfortáveis, comentários e também com questionamentos.

Nessa relação de interferência direta dentro da criação da cena, criamos esta possibilidade de contato direto com os que nos assistiam. $O$ aluno, ao se dirigir à plateia, obtém respostas sempre desconcertadas. Como resposta à pergunta o ator inicia uma fala escrita por ele, o que pra nós foi de grande valia pois seria um dos primeiros caminhos em busca da narrativa própria. Logo, como a resposta à pergunta, você é machista ou racista, temos a resposta do próprio aluno.

\footnotetext{
Ator: - A sociedade nos impõe isso a todo momento, e o que era para ser motivo de orgulho, a nossa razão acaba sendo uma coisa banal sem importância e de dizer, e essa sociedade nos dá nomes e os únicos nomes que nos dão é preto, favelado, puta. E pensar que essa mesma sociedade é composta em sua maioria, por negros e mulheres. (Douglas da Silva, 2017).
}

A cena segue com os demais alunos, caindo no chão ao ser dita as palavras "preto, favelado e puta", como imagem corporal que refletisse novamente o sinal de submissão. Ainda explorando a relação com o chão, os alunos se aproximam um dos outros fazendo uma linha frontal em direção a plateia. Agachados e perfilados no chão, os alunos colocam uma das mãos no ombro do outro e se inicia o terceiro slam de Mel Duarte (2016, p 22): "Não desista negra, não desista". Nesta parte de finalização da cena, buscamos retratar a importância da união como fonte de resistência como resolução conjunta para os temas que eram abordados dentro das aulas. 
Atriz 2: -Por mais que queiram esconder

Atriz 3: -Corre em tuas veias força yorubá,

Todos: -Axé!

Atriz 4: - Para que possa prosseguir!

Ator: - Eles precisam saber, que a mulher negra quer

Atriz 1: -Casa para morar

Atriz 2: - Água para beber,

Atriz 3: -Terra para se alimentar.

Atriz 4: - Que a mulher negra é

Ancestralidade,

Djembes e atabaques

Que ressoam dos pés. (DUARTE, 2016, p.12).

Também nesta parte da intervenção, buscamos ressignificar os elementos contidos nas religiosidades de matriz africana, e isso foi possível quando, em aula, fomos descobrir o que era um djembe, e por que o instrumento remete à esfera do que era sagrado, visto aqui como um elemento ligado à ancestralidade e história de um povo.

Estas descobertas eram paulatinamente inseridas ao lembrá-los que a história contada pelos livros sobre os negros no Brasil, por exemplo, não era necessariamente a história desse povo. Durante as oficinas a busca pela origem da história de cada um dos alunos era de fato o que movia o processo de criação. Descobrimos que a história destes povos passava pelas oralidades e corporeidades do hip-hop, bem como das danças africanas, onde o papel do negro era visto como o protagonista das invisibilizadas histórias. Seguindo com a intervenção, nesta cena temos:

\footnotetext{
Ator: - Que a mulher negra, tem suas convicções,

Atriz 1: - Suas imperfeições Como qualquer outra mulher.

Atriz 2: - Vejo que nós, negras meninas

Temos olhos de estrelas,

Atriz 3: - Que por vezes se permitem constelar

Atriz 4: - O problema é que desde sempre nos tiraram a nobreza

Ator: - Duvidaram das nossas ciências,

Atriz 1: - E quem antes atendia pelo pronome alteza

Hoje, pra sobreviver, Ihe sobra o cargo de empregada da casa

(DUARTE, 2016, p.12).
}

A cena a seguir foi retirada do contexto da lembrança do que eram as nossas raízes históricas como também poderiam ser nossas raízes familiares. Como raiz história, íamos debatendo, contextualizando e valorizando a cultura 
de rua negra e periférica, dentro das oficinas de teatro, reforçando a autoestima dos alunos. Já no contexto das raízes familiares, buscamos discutir sobre o papel da mulher negra e periférica como sendo a provedora destas raízes e, criamos assim a cena que se segue:

Atriz 2: - É preciso lembrar da nossa raiz semente negra de força matriz que brota em riste! Atriz 3: - Mãos calejadas, corpos marcados sim Mas de quem ainda resiste.

Atriz 4: - E não desiste negra, não desiste! Mantenha sua fé onde lhe couber Seja Espírita, Budista, do Candomblé.

Atriz 1: - É teu desejo de mudança, A magia que trás na tua dança, Que vai lhe manter de pé. (DUARTE, 2016, p.12).

$\mathrm{Na}$ cena que se segue, uma das alunas vai em direção à plateia apontando para as mulheres negras que estavam presentes nas apresentações, repetindo "é você, você [...] mulher negra". Se no slam, a fala estava sendo dirigida a uma pessoa ( mesmo que se comunicasse ao grupo social), na nossa adaptação para a cena, essa ênfase se dava pela necessidade que tínhamos de reconhecer dentro do contexto social a luta pela emancipação da mulher negra. A reflexo da aceitação dos corpos negros dentro das oficinas de teatro, foi sendo paulatinamente elaborado através da aceitação destes corpos e o entendimento de suas formas de expressão.

Atriz 2: - É você, é você, é você...mulher negra! Cujo tratamento majestade é digna! Livre, que arma seus crespos contra o sistema, Atriz 3: - Livre para andar na rua sem sofrer violência Atriz 4: -E que se preciso for, levanta arma, mas antes, luta com poema. (DUARTE, 2016, p.13).

A cena que finaliza a intervenção ressalta, antes de mais nada as temáticas trabalhadas na sala de ensaio como reflexo dos problemas enfrentados pelas quebradas, tais como a violência policial, a luta histórica do povo negro e a necessidade que essa luta seja vista e contada pelo próprio povo negro. Diante de cada temática trabalhada nas oficinas de teatro tínhamos, como resolução que somente dentro do coletivo tais denúncias poderiam ser 
questionadas. Relata a necessidade das histórias serem contadas partido do reconhecimento de suas origens históricas, e por sua vez ancestrais.

Todas: - E não desiste negra, não desiste!

Atriz 1: - Ainda que tentem Ihe oprimir

E acredite, eles não vão parar tão cedo.

Quanto mais você se omitir,

Ator: - Eles vão continuar a nossa história escrevendo!

Atriz 2: - Quando olhar para as suas irmãs, veja que todas somos o início:

Mulheres Negras!

Desde os primórdios, desde os princípios

África, mãe de todos!

Atriz 3: - Repare nos teus traços, indícios

É no teu colo onde tudo principia,

Atriz 4: - Somos as herdeiras da mudança de um novo ciclo!

$E$ é por isso que eu digo:

Todos: - Que não desisto!

Que não desisto!

Que não desisto!" (DUARTE, 2016, p.13).

Dessa forma, finalizamos o percurso de criação de nossa intervenção com base nos raps e slams, e fomos nos lançado para as apresentações. Os alunos então, entre os anos de 2016 e 2018, se apresentaram na cidade de Uberlândia e Uberaba, levando o nome do bairro a diferentes lugares. Nesse sentido, se faz necessário citar alguns desses lugares em que nos foi dada a oportunidade de compartilhar nossa criação:

- III- Mostra Teatral Olho da Rua, em Uberlândia na Escola Municipal Prof. Olga Del' Fávero (CAIC Laranjeiras);

- Saraus Culturais promovidos tanto em parceria com a Universidade Federal do Triângulo Mineiro, através do Coletivo AFRONTAR-SE (Empoderação da Pretas);

- Participação no Centro de Ensino Superior de Uberaba, promovida pelo curso de Educação Física da Faculdade de Ciências Econômicas do Triângulo Mineiro;

- Participação e premiação com menção honrosa no FEST-15, Festival promovido pela Universidade Federal do Triângulo Mineiro, em 2017;

- Participação na primeira edição do Slam Ondaka em Uberaba, onde fomos convidados a estar presente também com a intervenção. 
Além desses lugares, nos apresentamos diversas vezes na Escola Estadual Esther Limírio Brigagão, e nos eventos promovidos pelo CEU das Artes, no Residencial 2000. Estas apresentações realizadas no bairro, se não foram as mais importantes, para nós significaram estar perto dos pais, mães, tios, amigos de escola e em toda a comunidade.

Importante destacarmos também que conforme $\mathrm{o}$ grupo ia se apresentando. íamos agregando não só outros adolescentes moradores do bairro, como também, outros adolescentes de outros bairros da cidade, que começaram a frequentar as aulas. Além de adolescentes, também recebíamos universitários interessados em estabelecer trocas conosco e, em uma dessas trocas, conhecemos Gabriela ${ }^{11}$, até então, aluna de psicologia da Universidade Federal do Triângulo Mineiro, que junto conosco deve a iniciativa de mandar uma comunicação para o XIV Congreso Latinoamericano del Caribe de Extensión Universitaria ULEU y 2 Congreso Centroamericano de Compromiso Social CSUCA, realizado em Managuá (Nicarágua), onde fomos aprovados.

Esta comunicação foi escrita com a participação dos alunos, e os mesmos constam como autores da obra, fato este muito significativo, em se tratando de pensar a história contada a partir dos que fazem a história. Embora todos os nossos esforços para conseguir recursos financeiros, não conseguimos efetuar nossa participação.

\section{CONCLUSÃO}

Entendemos, então, que, quando utilizamos os elementos que estão dispostos dentro da própria comunidade, o teatro consegue oportunizar formas que mesclam arte e ativismo social. E que, para além do nível estético, oportunizou a pesquisa e a produção da própria comunidade através de inferências diretas dentro do espaço comunitário. Ocupamos com corpos negros os teatros oficiais, a escola, as quadras, as bibliotecas, as praças e as

\footnotetext{
${ }^{11}$ Gabriela Alves Martins Guimarães Lyrio Todo, hoje é formada em psicologia e atua com práticas do Teatro do Oprimido, em suas ações como psicóloga.
} 
universidades, marcando uma trajetória teatral na cidade de Uberaba entre os anos de 2016 a 2018, sendo um dos grupos de maior circulação e apresentação registradas na cidade neste período.

Do arsenal de Boal às poéticas das ruas, pudemos experienciar o teatro comunitário feito no Residencial 2000, ocupando o espaço público, a escola, e até mesmo o teatro. Uma intervenção cênica, fruto de um longo processo de oficinas, que refletiu, tanto pelas práticas teatrais formativas dentro de contextos sociais em que a realidade teima em saltar aos olhos e exigem um posicionamento daqueles que se propõem a construir novos caminhos; quanto pela necessidade desafiadora de que o teatro esteja efetivamente caminhando com o seu tempo, no melhor significado do sentido contemporâneo.

As incursões conceituais, empreendidas na tentativa de compreender as práticas por nós partilhadas com a comunidade do bairro Residencial 2000, sempre estiveram permeadas pelo "artivismo" (arte e ativismo social) que buscava disseminar não uma visão política preconcebida, mas sim, uma vivência dos pontos de tensão expressos nas diferentes segregações sociais.

Assim, as violências do cotidiano puderam ser elaboradas como matéria bruta de criação, em que o centro das narrativas e das ferramentas apresentadas aos jovens daquela comunidade construíram um resultado ético estético que também modificou ativamente o contexto social dos participantes.

A ação afetiva dos encontros talvez seja a definição que tenha tocado os corpos desses jovens, que se sentiram seguros em compartilhar não apenas o tempo, mas suas histórias, memórias e projetos de um futuro diferente, construídos por cada um que se colocava como parte desse coletivo.

\section{REFERÊNCIAS}

BOAL, Augusto. Jogos para atores e não- atores. Rio de Janeiro: Civilização Brasileira, 2004.

Teatro do oprimido e outras poéticas políticas. Rio de Janeiro: Civilização Brasileira, 1984.

DUARTE, Mel. Negra, nua, crua. São Paulo: Ijumaa, 2016. 
ESTRELA D’ALVA, Roberta. Teatro hip-hop. São Paulo: Perspectiva, 2015.

FREIRE, Paulo. Pedagogia do oprimido. Rio: Paz e Terra, 1977.

Pedagogia da autonomia: saberes necessários à prática educativa. São Paulo: Paz e Terra, 1996.

HUIZINGA, Johan. Homo ludens. São Paulo: Perspectiva, 2012.

NOGUEIRA, Márcia Pompeo. Teatro e Comunidade. In: TELLES, Narciso; FLORENTINO, Adilson (Orgs.). Cartografias do ensino de teatro. Uberlândia: Edufu, 2009.

Teatro e comunidade. Florianópolis: Udesc, 2009.

. Tentando definir o teatro na comunidade. [S.I.]: Virtual Books, 2007. Disponível em:<http://www.udesc.edu.br/ceart pompeoS\%E1vio.pdf Acesso em: 3 abr. 2019.

. A opção pelo teatro em comunidades: alternativas de pesquisa. Revista Urdimento, Florianópolis, n. 10, p.127-136.

Recebido em: 07/09/2020

Aprovado em: 23/02/2021 